\title{
Reverse osmosis effluents: biogeochemical and mineralogical investigation
}

\author{
ENCARNACIÓN RUIZ-AGUDO ${ }^{1}$, LUCIAN C STAICU ${ }^{2}$, \\ PAULINA J WOJTOWICZ ${ }^{2}$, MIHÁLY PÓSFAI ${ }^{3}$, DIEGO \\ BARAGAÑO COTO ${ }^{4}$ AND JOSÉ LUIS R GALLEGO ${ }^{4}$ \\ ${ }^{1}$ University of Granada (Spain) \\ ${ }^{2}$ University of Warsaw \\ ${ }^{3}$ University of Pannonia \\ ${ }^{4}$ University of Oviedo \\ Presenting Author: encaruiz@ugr.es
}

Industry is constantly searching for methods to treat waste fluxes in an attempt to minimize its environmental impact. Reverse osmosis (RO) is an efficient treatment system, generating a permeate stream (purified water passing through the membrane) and a retentate stream, which concentrates the constituents rejected by the membrane. Currently, a hot research area is the treatment of the retentate, as it is a high-strength and metal-rich solution of environmental significance. In this study, we present a multidisciplinary approach involving bioremediation and chemical precipitation for the treatment of a real retentate (As $\sim 2300 \mu \mathrm{g} \mathrm{L}^{-1}, \mathrm{Se} \sim 160 \mu \mathrm{g} \mathrm{L}^{-1}, \mathrm{SO}_{4}{ }^{2-} \sim 1500 \mathrm{mg}$ $\mathrm{L}^{-1}, \mathrm{HCO}_{3}^{-} \sim 480 \mathrm{mg} \mathrm{L}^{-1}, \mathrm{Ca}^{2+} 520 \mathrm{mg} \mathrm{L}^{-1}$ etc.) generated by a full-scale RO unit. The biological treatment involves the use of Shewanella $\mathrm{sp}$. O23S, a metal-resistant bacterium specialized in the metabolism of arsenic (As) and selenium (Se) [1, 2]. The bacterium has the capacity to reduce $\mathrm{As}(\mathrm{V})$ to $\mathrm{As}(\mathrm{III})$ and $\mathrm{Se}(\mathrm{VI})$ and $\mathrm{Se}(\mathrm{IV})$ to biogenic $\mathrm{Se}(0)$ through anaerobic respiration. Various electrons donors were tested, and the investigation was complemented by a thermodynamic competition study using $\mathrm{As}(\mathrm{V}), \mathrm{Se}(\mathrm{VI})$, and $\mathrm{Se}(\mathrm{IV})$, single and in combination. The analytics used included ICP-MS, ion chromatography, mineralogical and electron microscopy analysis. The inoculum performed best against $\mathrm{Se}(\sim 60 \%$ removal) with lactate as electron donor, while the addition of cysteine led to a higher performance $(\sim 87 \%)$. The chemical approach involved the precipitation of sulfate as barite, $\mathrm{BaSO}_{4}$, a mineral with high commercial value [3], at different contact times and $\mathrm{Ba}: \mathrm{SO}_{4}$ concentrations. Process optimization resulted in $>70 \% \mathrm{As}, \sim 79 \%$ Mo, and $>80 \%$ Se removal with barite. An in-depth mineralogical characterization of $\mathrm{BaSO}_{4}$ was performed and the removal mechanism of the contaminants was proposed and discussed.

[1] Uhrynowski et al. (2019) Int. J. Mol. Sci. 20, 1018. [2] Staicu et al. (2021) in preparation. [3] Staicu et al. (2020) Minerals 10, 188. 